\title{
Preparation of Lead Dioxide Electrodes. II.
}

\author{
K.C. Narasimham, S. Sundararajan and H.V.K. Udupa
}

Central Electrochemical Research Institute, Karaikudi-3, South India

Deposition of lead dioxide on carbon substrate from lead nitrate bath is described as a suitable method of obtaining desired size anodes for electrolytic oxidations. Twenty four electrodes with $1 \mathrm{~mm}$ thick deposit have been prepared using $2.5 \mathrm{~cm}$ diameter, $30 \mathrm{~cm}$ long carbon rods. Similarly, larger sized graphite substrate lead dioxide anodes (12 Nos.) using $7.5 \mathrm{~cm}$ diameter, $30 \mathrm{~cm}$ long graphite rods have been prepared with $0.5 \mathrm{~mm}$ thick deposit.

The cell assembly used and the procedure adopted for the deposition of lead dioxide on the above mentioned substrates are described. Anode potential measurement data obtained during deposition is discussed.

The distribution of lead dioxide on the substrate has been found out by measuring the thickness of the deposit throughout the length of the electrode.

Both carbon and/or graphite substrate anodes have been successfully employed in the preparation of perchlorates.

\section{Introduction}

The use of lead dioxide electrodes as non-metallic insoluble anodes in place of platinum in various electrolytic oxidation processes has come to much prominence in recent years. As already reported ${ }^{1)}$ considerable amount of work has been carried out by several workers on the preparation of suitable lead dioxide electrodes using different baths. Lead nitrate bath ${ }^{1 \sim 6)}$ has been found to be the most suitable for the purpose. Different substrates were used for the deposition of lead dioxide and various methods of contact on lead dioxide have been suggested when using it as anodes. Kato and Koizumi ${ }^{\text {r) }}$ reported deposition of lead dioxide on graphite but no detailed data were published by them. The present authors have described earlier ${ }^{1,2)}$ a method of deposition of lead dioxide on graphite substrate which has proved advantageous in many respects, particularly in overcoming the difficulty of making electrical contact on the lead dioxide. The graphite core itself acted as the lead for the current and the deposit of lead dioxide was smooth, very adherent and free from pores. This method of deposition of lead dioxide on graphite substrate serves a dual purpose (a) of effecting electrical contact to lead dioxide electrode and (b) of protecting the graphite from disintegration during electrolysis. Electrodes of desired shapes and dimensions could be obtained by employing the technique described earlier ${ }^{1,2)}$. Fairly thin deposits of lead dioxide $(0.2$ to $5 \mathrm{~mm}$ ) over graphite base was found to serve well as anodes in oxidation processes, thereby obviating the difficulty of handling massive, brittle lead dioxide electrodes as has been prepared by earlier workers.

The present paper deals with the preparation of bigger size lead dioxide electrodes deposited over both graphite and carbon substrates. The carbon rods cannot normally be employed as anodes in electrolysis without serious disintegration of the same taking place, but a layer of lead dioxide on it successfully protects it, in addition to acting as lead dioxide anode.

\section{Experimental}

Cell assembly : The cell assembly differed with the size of electrodes used for the deposition of lead dioxide. Three different sizes of graphite or carbon rods were used for the deposition of lead dioxide. 
The deposition was carried out on cylindrical graphite or carbon rods with rounded end, the diameter and length of which are $2.5^{\phi} \times 17.8 \mathrm{~cm}, 2.5^{\phi} \times 30.4 \mathrm{~cm}$ and $7.5^{\phi} \times 30 \mathrm{~cm}$. These were kept vertically at the centre of the container and were rotated during electrodeposition. The electrolysis containers in which the deposition was carried out were hard rubber cylindrical tank of $11.4^{\phi} \times 22.9 \mathrm{~cm}$ and cylindrical copper vessels of $10^{\phi} \times 44 \mathrm{~cm}$ and $15^{\phi} \times 47.5 \mathrm{~cm}$ with rounded bottom. These containers had an outlet at the top for overflow of electrolyte. The containers were kept in a thermostat. U-shape copper strips or the copper container acted as cathode.

Electrolyte : The electrolyte contained $350 \mathrm{~g} / \mathrm{l}$ of lead nitrate and $20 \mathrm{~g} / \mathrm{l}$ of copper nitrate. The specific gravity of the liquor prior to the electrolysis was measured by a hydrometer and was found to be 1.27. Large quantities of electrolyte were prepared and the electrolyte circulated so as not to allow the $\mathrm{pH}$ to be below 1.5. The nitric acid formed during the electrolysis was neutralised by addition of lead carbonate or lead monoxide and copper carbonate (enough to replace the copper deposited) to the electrolyte outside the cell. Evaporation losses during deposition was made up by adding water so that the density of the electrolyte was maintained.

Pretreatment of the anodes: In all the experiments the graphite or carbon anodes were given an alkali treatment by using them as anode and a copper strip as cathode in $10 \%$ (w/v) sodium hydroxide solution employing an anodic current density of $10 \mathrm{amp} / \mathrm{dm}^{2}$ for 5 to 10 minutes. Later, it was washed in running water and dipped in $20 \%$ (v/v) nitric acid for two minutes to remove the alkali, washed and dried. The dried electrode was weighed before electrolysis and the diameter of the rod was measured at $1 \mathrm{~cm}$ intervals at different places. Sometimes the graphite electrodes are kept in distilled water before deposition is started.

Electrolysis : After inserting the electrodes in the rotating shaft, it was adjusted to give uniform rotation and the r.p.m. measured. The electrolyte, at desired temperature, was allowed to flow through the cell from a storage tank. Direct current from a selenium rectifier was switched on even before the electrolyte was filled into the cell. The interelectrode distance was adjusted to be the same from all sides. The current was adjusted so as to obtain the desired anode current density (5 to $7 \mathrm{amp} / \mathrm{dm}^{2}$ ). The flow was adjusted so as to maintain the $\mathrm{pH}$ between 1.5 and 2.5. The solution after neutralisation as stated earlier, was filtered and recirculated. After electrolysis the graphite or carbon anode with the lead dioxide deposit was removed from the cell, washed thoroughly, dried and weighed. The current efficiency was calculated from the weight of lead dioxide deposited. The diameter of the electrode was measured at places along the length of electrode at the same intervals as before so as to obtain the thickness of the deposit from the surface level to the end of the anode. Thickness is shown in Table 1.

The conditions of electrolysis are given in Table 1. 24 numbers of $2.5^{\phi} \times 30.4 \mathrm{~cm}$ carbon substrate lead dioxide electrodes and 12 numbers of $7.6 \mathrm{~cm}$ diameter $\times 30.4 \mathrm{~cm}$ height graphite substrate lead dioxide electrodes were prepared. Fig. 1 is a photograph of the different size electrodes prepared.

3 numbers of $2.5^{\phi} \times 30.4 \mathrm{~cm}$ electrodes prepared at 30 $35^{\circ} \mathrm{C}$ having a $1.5 \mathrm{~mm}$ thick lead dioxide deposit were used as anodes in a 90 ampere perchlorate cell using conditions standardized earlier ${ }^{8}$. After using them for the passage of

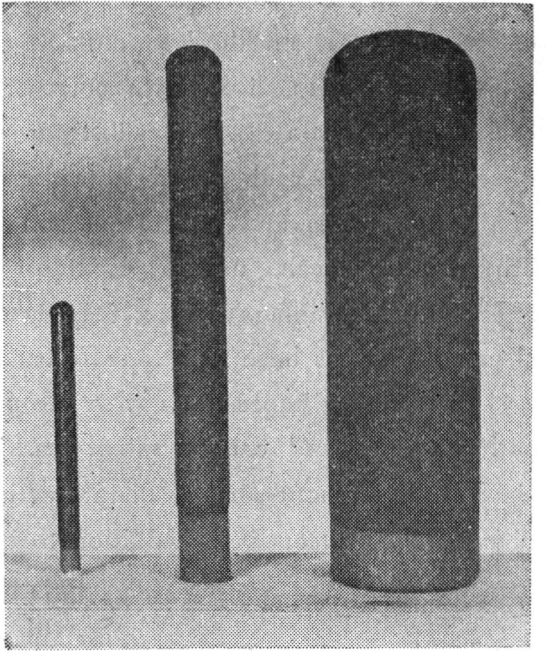

Fig. 1 Different sizes of Graphite/Carbon substrate lead dioxide electrodes 


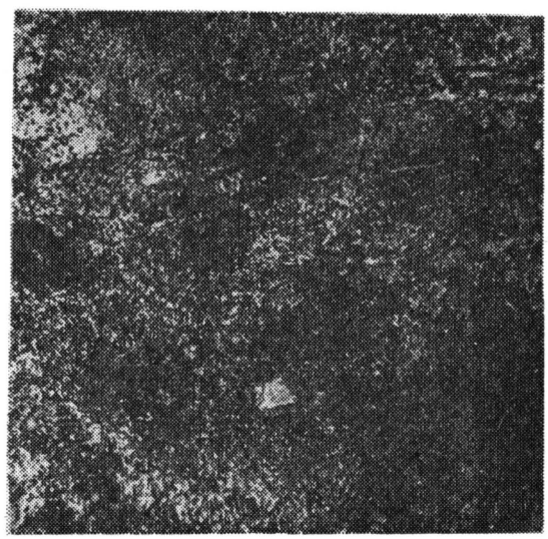

A
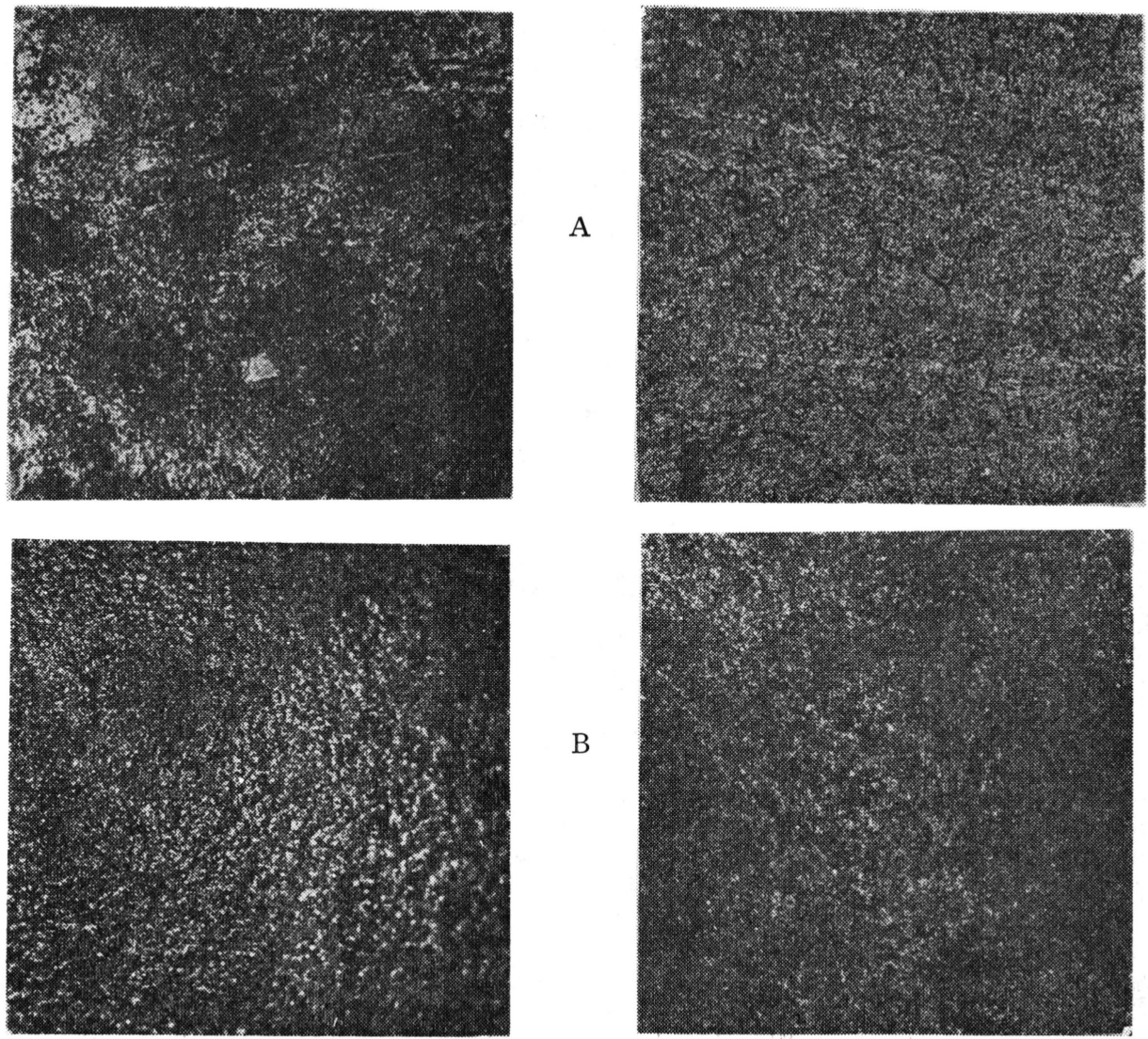

1

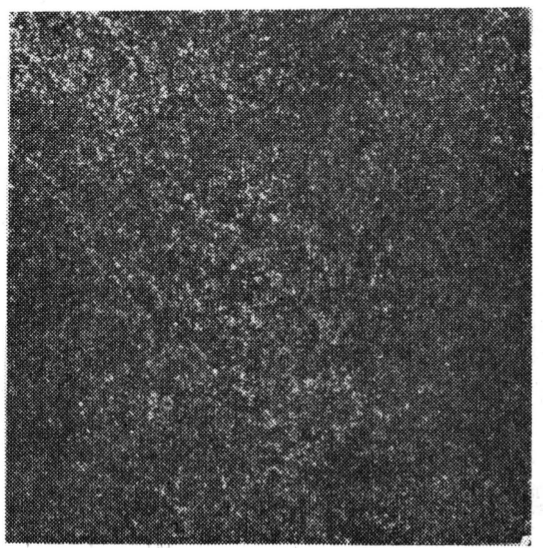

1. Before use 2. After use

A : $1 \mathrm{~cm}$ rod $\quad$ B : $2.5 \mathrm{~cm} \mathrm{rod}$

Fig. 2 (a) Photomicrographs of lead dioxide surface
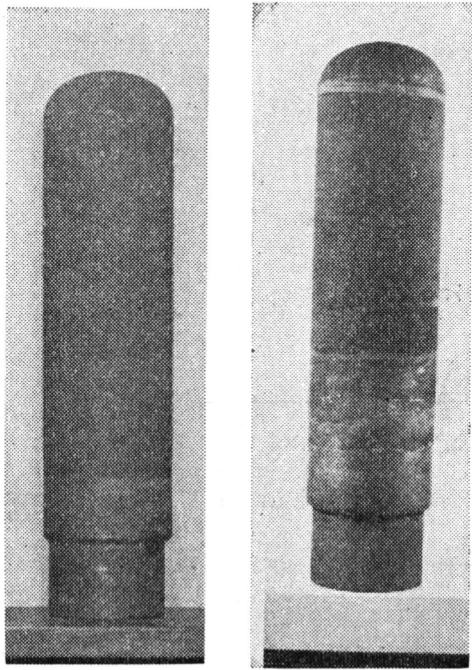

2. After use

Fig. 2 (b) Photograph showing lead dioxide anode $(7.5 \mathrm{~cm}$ dia. $\mathrm{rod})$ before and after use

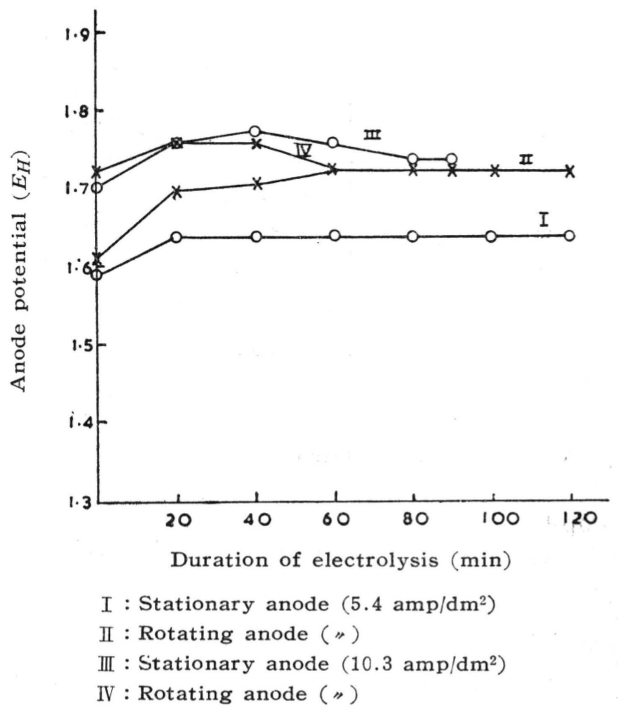

Fig. 3 Duration of electrolysis vs. anode potential 
Table 1 Data on the Preparation of Large Size Lead Dioxide Electrodes

Electrolyte, $350 \mathrm{~g} / l \mathrm{~Pb}\left(\mathrm{NO}_{3}\right)_{2} ; 20 \mathrm{~g} / l \mathrm{Cu}\left(\mathrm{NO}_{3}\right)_{2}$; Specific gravity of electrolyte, 1.27; Cathodecum-container, Copper

\begin{tabular}{|c|c|c|c|c|c|c|c|}
\hline $\begin{array}{l}\text { Expt. } \\
\text { No. }\end{array}$ & $\begin{array}{l}\text { Anode } \\
\text { material }\end{array}$ & $\begin{array}{l}\text { Diameter } \\
\text { of anode } \\
(\mathrm{cm})\end{array}$ & $\begin{array}{c}\text { Bath } \\
\text { Voltage } \\
\text { (volts) }\end{array}$ & $\begin{array}{c}\text { Current } \\
\text { (amps) }\end{array}$ & $\begin{array}{c}\text { Duration of } \\
\text { electrolysis } \\
\text { hrs. min. }\end{array}$ & $\mathrm{pH}$ & $\begin{array}{l}\text { Temp. } \\
\left({ }^{\circ} \mathrm{C}\right)\end{array}$ \\
\hline 1 & Carbon & $2.64-2.65$ & 2.2 & 10.0 & 0 & $1.5-2.5$ & $32-36$ \\
\hline 2 & Carbon & $2.74-2.75$ & 2.5 & 10.0 & 4 & $1.5-2.5$ & $30-35$ \\
\hline 3 & Carbon & 2.56 & 2.8 & 12.0 & 30 & $1.5-2.5$ & 30 \\
\hline 4 & Carbon & $2.5-2.56$ & 2.6 & 12.0 & 30 & $2.0-2.5$ & 31 \\
\hline 5 & Carbon & $2.57-2.59$ & 2.6 & 12.0 & 25 & $1.5-2.5$ & 32 \\
\hline 6 & Carbon & $2.64-2.65$ & 1.8 & 10.0 & 0 & $2.0-2.5$ & 60 \\
\hline 7 & Carbon & 2.6 & 2.3 & 12.0 & 20 & $1.5-2.5$ & $60-65$ \\
\hline 8 & Carbon & 2.67 & 1.8 & 10.0 & 4 & $1.5-2.5$ & $60-65$ \\
\hline 9 & Carbon & $2.61-2.62$ & 2.0 & 12.0 & 30 & $1.5-2.5$ & $55-65$ \\
\hline 10 & Graphite & 7.7 & $2.8-3.0$ & 25.0 & 30 & $1.5-2.5$ & $60-65$ \\
\hline 11 & Graphite & 7.77 & $2.8-3.0$ & 25.0 & 00 & $1.5-2.5$ & $60-65$ \\
\hline $\begin{array}{c}\text { Expt. } \\
\text { No. }\end{array}$ & $\begin{array}{c}\text { Anode } \\
\text { current } \\
\text { density } \\
\left(\mathrm{amp} / \mathrm{dm}^{2}\right)\end{array}$ & $\begin{array}{l}\text { Weight of } \\
\text { lead dioxide } \\
\text { deposited } \\
(\mathrm{g})\end{array}$ & $\begin{array}{c}\text { Thickness } \\
(\mathrm{mm})\end{array}$ & $\begin{array}{l}\text { Current } \\
\text { efficiency } \\
(\%)\end{array}$ & \multicolumn{3}{|c|}{ Nature of deposit } \\
\hline 1 & 5.5 & 184 & $0.85-0.90$ & 100 & \multirow{11}{*}{\multicolumn{3}{|c|}{$\begin{array}{l}\text { smooth, adherent without pinholes } \\
\text { smooth, adherent grey in colour } \\
\text { adherent with striations } \\
\text { adherent, smooth without pittings } \\
\text { " } \\
\text { adherent without pinholes } \\
\text { rough and adherent } \\
\text { smooth, adherent without pinholes } \\
\text { " }\end{array}$}} \\
\hline 2 & 5.0 & 196 & $1.05-1.1$ & 100 & & & \\
\hline 3 & 5.8 & 193 & $1.1-1.2$ & 100 & & & \\
\hline 4 & 7.0 & 184 & $1.3-1.35$ & 98.2 & & & \\
\hline 5 & 7.0 & 199 & $1.1-1.2$ & 100 & & & \\
\hline 6 & 5.5 & 175 & $0.85-0.95$ & 98.0 & & & \\
\hline 7 & 6.7 & 181.5 & $0.9-0.95$ & 100 & & & \\
\hline 8 & 5.1 & 171.0 & $0.75-0.8$ & 95.8 & & & \\
\hline 9 & 5.8 & 167.5 & $1.0-1.1$ & 93.8 & & & \\
\hline 10 & 4.6 & 430.0 & 0.50 & 85.7 & & & \\
\hline 11 & 4.8 & 595.3 & $0.50-0.60$ & 100 & & & \\
\hline
\end{tabular}

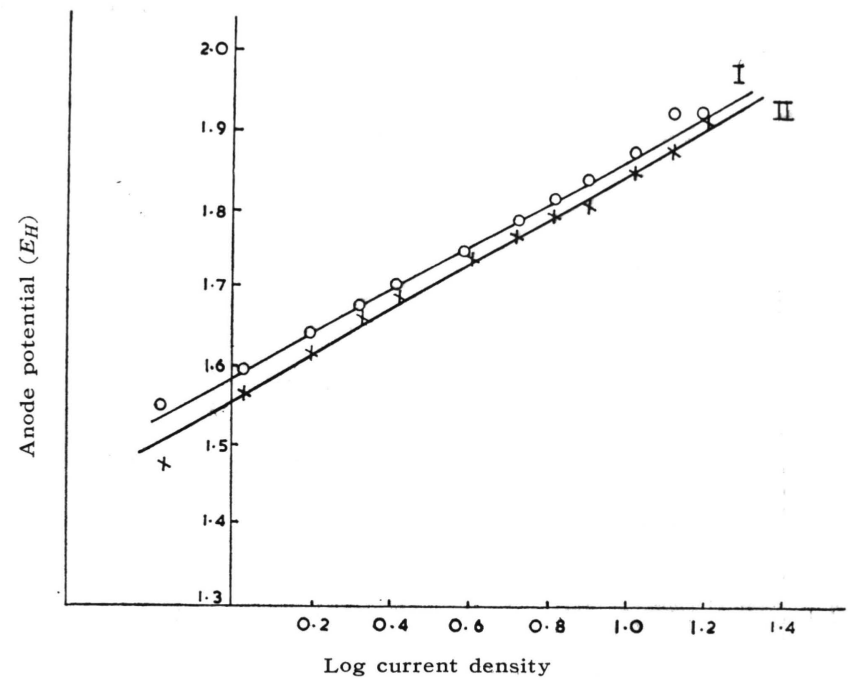

Fig. 4 Log current density vs. anode potential for (I) stationary and (II) rotating anodes

15,000 amp-hrs per electrode (each electrode carrying $30 \mathrm{amp}$ current) at a temperature of $42-45^{\circ} \mathrm{C}$, the electrodes were found to be still serviceable ${ }^{9}$. The surface of the lead dioxide which was immersed in the electrolyte, however, was observed to have changed in all cases from black or grey to brownish colour after electrolysis. No appreciable loss in weight could be seen by weighing the electrodes before and after the electrolysis. Photograph showing the surface transformation is also. given (Fig. 2). 


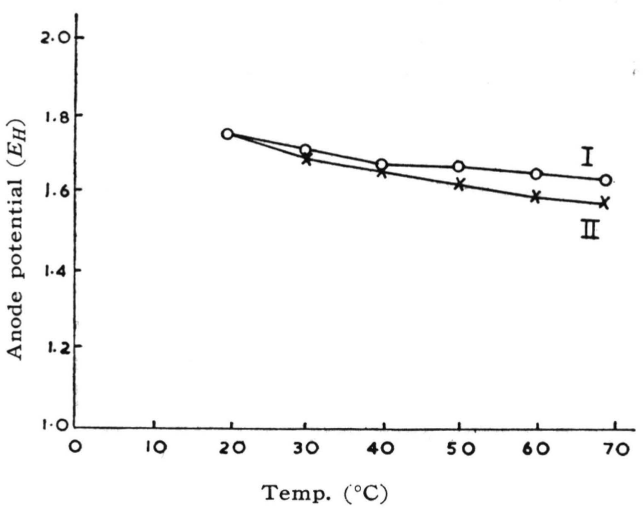

Fig. 5 Temperature $v s$. anode potential for (I) stationary and (II) rotating anodes at an anode current density of $5.1 \mathrm{amp} / \mathrm{dm}^{2}$

Anode potential measurements : Potentials were measured during the deposition of lead dioxide on a $1 \mathrm{~cm}$ diameter graphite rod against a saturated calomel electrode using a vacuum tube voltmeter (D.C. Philips No. 6010 type). When the potentials were measured during electrolysis at different current densities under stationary and rotating conditions, it was observed that the anode potentials were higher in the latter case, but the differences became less at high current densities (Fig. 3). When, however, the potential for stationary and rotating conditions of the same anode was measured using 3 minutes of electrolysis for each condition, it was observed (Fig. 4) that the values were higher for the stationary anode. The potentials were also measured for different temperatures on the same anode as above and the results are given in Fig. 5.

The results of anode potential measurements may be summarized as follows:

The anode potential increases initially upto a short duration of electrolysis, after which it is fairly steady (Fig. 3). Increasing the current density for deposition results in considerable anodic polarization (Fig. 4). However, increase of temperature decreases the anodic polarization (Fig. 5).

\section{Acknowledgment}

The authors sincerely thank Professor K.S.G. Doss, Director of the Institute for his keen interest and useful discussions during the course of this work. The authors also thank Sarvashri S. Sampath, N. Ramachandran and V. Dhuruvan for the help in the preparation of the lead dioxide electrodes. The authors express their sincere thanks to Prof. K. Sugino for kindly communicating this paper to this Journal.

(Received Apr. 27, 1961)

\section{Literature :}

1) K.C. Narasimham, H.V.K. Udupa "Preparation of lead dioxide electrodes-Part I" presented at the symposium on "Electrolytic Cells" held at Karaikudi (India) in December 1958 (under publication).

2) H.V.K. Udupa, K.C. Narasimham, Indian Patent No. 66195, December 22 (1958).

3) K. Sugino, Y. Shibasaki, Denki-Kagaku 16, 9-13 (1948).

4) K. Sugino, Bull. Chem. Soc. Japan 23, 115 (1950).

5) J.C. Grigger, H.C. Miller, F.D. Loomis, J. Electrochem. Soc. 105, 100 (1958).

6) J.C. Schumacher, D.R. Stern, P.R. Graham, J. Electrochem. Soc. 105, 151 (1958).

7) Y. Kato, K. Koizumi, Denki- Kagaku 2, 309 (1934).

8) K.C. Narasimham, S. Sundararajan, H.V.K. Udupa, J. Electrochem. Soc. 108, 798 (1961).

9) K.C. Narasimham, S. Sundararajan, H.V.K. Udupa, unpublished work. 